\title{
Sosyal Medyanın Üniversite Öğrencilerinin Satın Alma Davranışlarına Etkisi Üzerine Kavramsal Bir Bakış*
}

\section{A Conceptual Perspective for the Influence of Social Media on University Students' Buying Behaviors}

\author{
Seda Yildırım, ${ }^{\text {a,*** }}$ Mert Kalender ${ }^{\mathrm{b}}$ \\ ${ }^{a}$ Doç. Dr., Namık Kemal Üniversitesi, İktisadi ve İdari Bilimler Fakültesi, İşletme Bölümü, 59030, Tekirdağ/Türkiye. \\ ORCID: 0000-0003-4367-6652

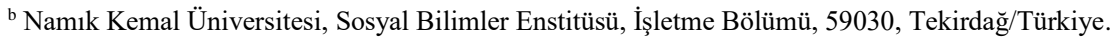 \\ ORCID: 0000-0002-3969-0745
}

\section{MAKALE BILGGISI}

\section{Makale Geçmişi:}

Başvuru tarihi: 08 Şubat 2018

Düzeltme tarihi: 12 Mart 2018

Kabul tarihi: 16 Mart 2018

\section{Anahtar Kelimeler:}

İnernet

Sosyal Medya

Üniversite Öğrencileri

Satın Alma Davranıșları

\section{ART ICLE INFO}

\section{Article history:}

Received 08 February 2018

Received in revised form 12 March 2018

Accepted 16 March 2018

\section{Keywords:}

Internet

Social Media

University Students

Buying Behaviour
ÖZ

Sosyal medya kullanımının gittikçe yaygınlaşması ve özellikle genç kitleler tarafından daha çok tercih edilmesi, bu alanda yapılan çalışmaların önemini arttırmıştır. Ülkemizde de sosyal medya gençler tarafından sıklıkla kullanılmakta olup, işletmelerin ve markaların dikkatleri sosyal medya araçlarına yönelmiştir. Bu noktada, çalışmanın amacı sosyal medyanın üniversite öğrencilerinin satın alma davranışlarına etkisini kavramsal bir çerçevede incelemek ve araştırmaktır. Amaç doğrultusunda, Türkiye'de yapılan son araştırmalardan, raporlardan ve çeşitli akademik çalışmalardan yararlanılmış, bazı temel bulgular ve sonuçlara elde edilerek, yorumlanmıştır. Bu çalışmanın en önemli kısıtı, tarama modelinin kullanılması ve sadece Türk literatüründen yararlanılmasidir.

\section{A B S T R A C T}

Increasing usage of social media and greater preference, especially by young masses, has increased the importance of researches in this area. In our country, social media is mostly used by young people, and the attention of businesses and brands has turned to social media tools. In this point, the aim of the study is to examine and investigate the influence of social media on the buying behaviours of university students in a conceptual framework. In accordance with this aim, recent studies, reports and some academic works in Turkey were used and then some basic findings and results were concluded. The most important limitation of this study is the use of the screening model and the utilization of only Turkish literature.

\section{Giriş}

Teknolojinin insanlığga kazandırdığı en önemli gelişmelerden biri olan internet teknolojisi, dünya genelinde hılı bir şekilde yaygınlaşmış ve kabul görmüş ender teknolojilerden biridir. İternet, esasen "Interconnected Networks" kelimesinin İngilizceden kısaltılmasıdır (Başhan, 2011: 2). İnternet ile kişiler birbirleriyle etkileşimli olarak iletişim kurmakta ve bu etkileşimi sürekli olarak ağlar sayesinde devam ettirebilmektedirler. Küresel ağ olarak değerlendirilen internet kavramı, büyük bir a $\breve{g}$ sistemidir (Mestçi, 2013: 217). İnternet sisteminin bilgi ağlarının bir birleşimi olarak küresel boyut taşıması, bu sistemin ilk olarak araştırma amaçlı ve devlet kurumları tarafindan kullanılmasını sağlamıştır (Gün, 1999: 29). İnternet sistemi

\footnotetext{
* Bu çalışma, 2017 yılında Namık Kemal Üniversitesi Sosyal Bilimler Enstitüsü tarafından kabul edilen "Sosyal Medyanın Üniversite Ögrencilerinin Satın Alma Davranışları Üzerindeki Etkisi” adlı Yüksek Lisans tezinden türetilmiştir.

** Sorumlu yazar/Corresponding author.

e-posta: sedayildirim@nku.edu.tr
} 
bütün ağların birbirine bağlanmasını sağladı̆̆ı için aslında tek bir bütün ağ olup, ağların babası olarak da adlandırılmaktadır (Beceren, 1997: 15). Bu büyük ağ ile insanlar istedikleri resim, ses ve grafik gibi şeyleri kullanarak iletişim kurabilirler (Y1ldırım, 2014: 51). İnternet sistemi için dönüm noktasının "www" "nin çıkışı olduğu söylenebilir. 1990'larda "World Wide Web(www)" sisteminin geliştirilmesi ile birlikte bilgilerin birbirine bağlı bilgisayarlar aracılığıyla aktarılması kolaylaşmış ve bilginin aranması küresel hale gelmiştir. Ayrıca her kurum ya da özel işletmenin kendi sitesinin kurabileceği bir alan yaratılmış oldu (Aktaş, 2007: 32). Günümüzdeki hali ile internet sayesinde şu temel hizmetler yerine getirilmektedir (Uzundağ, 2013: 26): "Elektronik posta(e-mail) hizmetleri, FTP (dosya transfer protokol), WWW (World wide web), Telnet, Usenet-News(haber grupları), IRC (internette canlı söyleşi)".

World Wide Web sonrasında internet teknolojisi açısından önemli ikinci adımın "Web 2.0"'ın ortaya çıkışı olduğu söylenebilir. Çünkü Web 2.0 teknolojisi, sosyal medyayı hayata kazandırmıştır. Sosyal medya ise ağları herkesin en çok tercih ettiği ve kullandığı bir internet teknolojisi haline gelmiştir (Aydede, 2006: 34). İnsanların küresel etkileşimlerinin artmasına yardımcı olan sosyal medya ağları, yeni bir medya türü olarak artık her alanda kendini göstermektedir. Bu teknoloji ile geleneksel tek taraflı iletişimin yerini çift yönlü iletişime bıraktığ 1 görülmektedir (Küçükali, 2016: 532). Sosyal medya iş dünyasına da damgasını vurmuştur. Markalar, işletme yöneticileri, reklamcılar, gazeteciler vb. gruplar tarafından da yoğun olarak kullanılan bir medya alanı olarak sosyal medya ortamları öne çıkmaktadır (Bozkurt, 2006: 50). Sosyal medya, Web 2.0 temelli teknolojik alt yapıya bağlı olarak, kullanıcıların bir araya gelmesi ve birbirleriyle iletişim kurmaları sonucu gelişen bir sistem olarak düşünülebilir. Sosyal medyada insanlar iletişim kurarken, "kelimeler, resimler, videolar vb." araçlardan da yararlanabilmektedirler (Keskin ve Baş, 2015: 54).

Sosyal medya araçlarının hızlı yükselişi, pazarlamacıların da dikkatini çekmiş ve yeni pazarlama faaliyetleri için yaratıcı teknikler ortaya çıkmıştır. $\mathrm{Bu}$ bağlamda sosyal medya pazarlaması kavramının doğduğu söylenebilir. Sosyal medya pazarlaması, insanlar sosyal medya ortamlarında her çeşit ürünün tanıtımının yapıldığı ve diğer pazarlama faaliyetlerine destek olabilecek fonksiyonların da olduğu, tüketiciler ile bire bir iletişimin kurulduğu yeni bir pazarlama konseptidir (Aksoy, 2006: 34). Özellikle marka tanınırlığı, marka kimliğine değer katma, kurum itibarı gibi durumlar için sosyal medyanın işletmelere çok iyi avantajlar sağlamaktadır. Sosyal medyanın çift yönlü iletişim fonksiyonu tüketici-işletme ilişkileri için çok faydalıdır (Özel, 2012: 60). Sosyal medya, pazarlama tutundurma faaliyetleri yönünden ise işletmelere düşük maliyetle daha çok kitleye ulaşma imkânı sağlayan bir sistem oluşturmaktadır. Pazarlamanın daha hızlı ve etkin hale gelmesi sosyal medyada mümkündür. Sosyal medyada pazarlama faaliyetlerinin tüketiciler açısından çekici hale getirilmesi çalışmaları işletmeler için odak noktası olmuştur (Akar, 2011: 38).

Sosyal medyanın pazarlamacılar açısından da önemi göz önünde alındığında bu alanda yapılan çalışmalar öne çıkmaktadır. $\mathrm{Bu}$ çalışmanın amacı sosyal medyayı çoğunlukla kullanan kitle olarak gençlerin satın alma davranışlarını teorik olarak incelenmesidir. $\mathrm{Bu}$ bağlamda çalışmamızda sosyal medyanın üniversite öğrencilerinin satın alma davranışlarına olan etkisi kavramsal bir yaklaşımla değerlendirilmiş ve yorumlanmıştır. Dünya literatüründe kültür ve diğer faktörlerin de etkisi bazı değişikliklere yol açacağından dolayı, çalışmada sadece Türkiye içerisinde yapılan akademik çalışmalar ve diğer rapor ve göstergelerden yararlanılmıştır.

\section{Sosyal Medya Kavramı İçin Genel Çerçeve}

Türkiye'de internet teknolojisi 1994 yılında başladı ancak sosyal medya gelişimi ülkemizde çok eski değildir. Dünya'ya göre biraz daha geriden gelmesine rağmen, günümüzde Türkiye'de sosyal medya kullanımı oldukça yaygındır (Küçükali, 2016: 533). Kullanıcılar sosyal medya ortamlarında birçok özelliğe kavuşabilmekte ve bunlar yardımıyla iletişimlerinde etkinliğe ulaşabilmektedirler. $\mathrm{Bu}$ yönüyle, sosyal medya araçları da daha iyisini bulabilmek için sürekli olarak yenilenmekte ve gelişmektedir (Kahraman, 2013: 43). Sosyal medyanın gelişiminde öncelikle internet teknolojilerinin gelişimi söz konusudur. Çünkü internet teknolojilerinin değişimi ve Web 2.0 teknolojisinin gelmesi sosyal medya için alt yapıyı oluşturmuştur. Bütün dünyada internette ulaşılabilirliğin artması da sosyal medya için başka bir alt yapı olarak değerlendirilebilir (Taş, 2015). Sosyal medyanın gelişiminde önemli dönüm noktaları şu şekilde sıralanabilir (Öncel, 2012):

- WWW'nin 1991'de ortaya çıkması,

- 1994'te ilk blog: 1995 'te kurulan Classmates.com,

- 1997'de weblog kavramı ortaya çıktı: Blogger ve LiveJournal alt yapıları geldi,

- 2000 yılı: Wikipedia açıldı,

- 2001 yılı: Stumbleupon açıldı,

- 2002 yılı Friendster açıldı,

- 2003 yılı Myspace açıldı,

- 2004 yılı Facebook açıldı.

Sosyal medya araçlarının gelişim sürecinin incelenmesi de sosyal medyanın tarihsel olarak nasıl bir ilerleme gösterdiği konusunda fikir verebilir. Tablo 1'de sosyal medya araçlarının gelişimi tarihsel olarak özetlenmiştir.

Sosyal medya kavramının anlaşılmasında bazı temel özellikler ön plana çıkmaktadır. Örneğin; Gürsakal (2009)'ın sosyal medya için belirttiği temel özellikler şu şekildedir (Gürsakal 2009'dan aktaran: Ergin, 2015: 17-18):

- Katılımcılar: Sosyal medyanın ilk özelliklerinden biridir. Sosyal medyada herhangi bir ağa bağlanan ya da üye olan kişiler burada katılımlarını gerçekleştirirler ve yaptıkları paylaşımlarla katılımlarını devam ettirirler.

- Açıklık: Sosyal medyada her türlü bilgi için bir açıklık söz konusudur.

- Konuşma: Kişiler sosyal medya ortamlarında karş1lıklı iletişim kurabilirler. 
- Topluluk: Sosyal medya ortamlarında ortak özellikler paylaşan gruplar bir araya gelmektedir.

- Bağlantısallık: Sosyal medya ortamlarına giriş için katılımcıların ya da kullanıcıların bağlanması gerekir.

Tablo 1. Sosyal Medya Araçlarının Tarihsel Gelişim Süreci

\begin{tabular}{|c|c|}
\hline Tarih & Sosyal Medya Araçları \\
\hline 2004 & $\begin{array}{ll}- & \text { Harvard öğrencilerine tanıtım } \\
\text { - } & \text { MySpace tanıtımı } \\
\text { - } & \text { Digg sosyal haber sitesi kuruldu } \\
\text { - } & \text { Flickr, fotoğraf, topluluk sitesi tanıtımı } \\
\text { - } & \text { Linkedln, profesyoneller için site kuruldu }\end{array}$ \\
\hline 2005 & $\begin{array}{ll}\text { - } & \text { Facebook genişledi şirketlere de yer verildi } \\
\text { - } & \text { YouTube.com aktif oldu. Video yükleme geldi } \\
\text { - } & \text { Reddit haber sitesi tanıtımı }\end{array}$ \\
\hline 2006 & $\begin{array}{ll}- & \text { Twitter tanıtımı } \\
\text { - } & \text { MySpace en çok ziyaret edilen site }\end{array}$ \\
\hline 2007 & - $\quad$ Tumblr mikroblog sitesi tanıtımı \\
\hline 2009 & $\begin{array}{ll}\text { - } & \text { Pinterest geldi } \\
\text { - } & \text { Facebook "beğen" seçeneği geldi } \\
\text { - } & \text { Fousquare kuruldu }\end{array}$ \\
\hline 2010 & - $\quad$ Instagram geldi \\
\hline 2011 & - Snapchat tanıtımı \\
\hline 2012 & $\begin{array}{ll}\text { - } & \text { Vine geldi } \\
\text { - } & \text { Pheed geldi } \\
\text { - } & \text { Suilia tanitım } 1 \\
\text { - } & \text { Thumb geldi } \\
\text { - } & \text { Tinder dikkatleri toplad } 1\end{array}$ \\
\hline 2013 & $\begin{array}{ll}\text { - } & \text { Medium tanıtımı } \\
\text { - } & \text { Kleek geldi } \\
\text { - } & \text { Viddy geldi }\end{array}$ \\
\hline 2014 & $\begin{array}{ll}- & \text { Atmospheir geldi } \\
\text { - } & \text { Learnist geldi }\end{array}$ \\
\hline 2015 & $\begin{array}{ll}\text { - } & \text { Periscope büyüdü } \\
\text { - } & \text { Scorp ilgi gördü }\end{array}$ \\
\hline
\end{tabular}

Kaynak: Taş (2015)'den uyarlanmıştır.

Ayrıca sosyal medya özellikleri şu şekilde de özetlenebilir (Egegen, 2017):

- Kullanıcı Hesapları: Sosyal medya kişiler kendileri için hesap açabilir.

- Profil Sayfaları: Sosyal medyada herkes kendisi için bir profil oluşturabilir.

- Arkadaşlar, Takipçiler, Gruplar, Hashtagler: Sosyal medyada kişiler, kendi düşüncelerini paylaşmak için çeşitli başılı araçları kullanabilir.

- Haberleşme: Sosyal medyada herkes birbiriyle bağlantı kurabilir.

- Kişiselleştirme: Sosyal medyada kişiler kendi blog vb. sayfalarını ve profillerini kişiselleştirebilirler.

Sosyal medya araçları denildiğinde, çok çeşitte ve sayıda araç karşımıza çıkmaktadır. Her aracın kullanım amacı ve şekli ise değişebilmektedir. Sosyal medya araçları açısından öne çıkanlar Tablo 2'de sunulmuştur.
Tablo 2. Sosyal Medya Araç Çeşitleri ve Siteleri

\begin{tabular}{|c|c|}
\hline $\begin{array}{l}\text { Sosyal medya araç } \\
\text { çeşitleri }\end{array}$ & Siteler \\
\hline \multicolumn{2}{|c|}{ İletişimin Ön Planda Olduğu Sosyal Medya Araçları } \\
\hline Blog siteleri & $\begin{array}{l}\text { Blogger, WordPress, Blogcu, } \\
\text { Livejournal, Open Diary, Typepad }\end{array}$ \\
\hline Mikro bloglar & Twitter, Plurk, Jaiku, Tumblr, Yammer \\
\hline Sosyal ağlar & $\begin{array}{l}\text { Facebook, MySpace, Hi5, LinkedIn, } \\
\text { Bebo, Orkut, Yonja, Netlog }\end{array}$ \\
\hline $\begin{array}{l}\text { Sosyal ağ } \\
\text { toplayıc1lar }\end{array}$ & Friendfeed, Nutshellmail, Nsyght, Orsiso \\
\hline Etkinlikler & Eventful, Zvents, Upcoming \\
\hline \multicolumn{2}{|r|}{ İşbirliği Ön Planda Olan Siteler } \\
\hline Wiki siteleri & Vikipedi, SocialText, MediaWiki \\
\hline Sosyal etiketleme & $\begin{array}{l}\text { Delicious, Marro.ws, Oyyla, } \\
\text { StumbleUpon, Google Reader }\end{array}$ \\
\hline Sosyal haberler & $\begin{array}{l}\text { Digg, Reddit, Mixx, Social News Turkey, } \\
\text { Slashdot, Bildirgeç }\end{array}$ \\
\hline & Multimedya Siteleri \\
\hline $\begin{array}{l}\text { Fotoğraf } \\
\text { paylaşımı }\end{array}$ & $\begin{array}{l}\text { Flickr, Photobucket, Picasa, Fotokritik, } \\
\text { Fotki, Webshots, Deviantart }\end{array}$ \\
\hline Video paylaşımı & $\begin{array}{l}\text { Youtube, Metacafe, Dailymotion, Vimeo, } \\
\text { İzlesene }\end{array}$ \\
\hline $\begin{array}{l}\text { Müzik, ses } \\
\text { paylaşımı }\end{array}$ & $\begin{array}{l}\text { Last.fm, fizy, Playlist, Hype Machine, } \\
\text { Kavun }\end{array}$ \\
\hline \multicolumn{2}{|c|}{ Görüş ve İzlenim Belirtilen Siteler } \\
\hline $\begin{array}{l}\text { Ürün ve iş } \\
\text { değerlendirme }\end{array}$ & Epinions, Yelp, Sikayetvar, T1klayaz \\
\hline $\begin{array}{l}\text { Soru ve cevap } \\
\text { toplulukları }\end{array}$ & $\begin{array}{l}\text { Yahoo! Answers, Answerbag, Sorucevap, } \\
\text { Bisorusor }\end{array}$ \\
\hline \multicolumn{2}{|r|}{ Eğlence Amaçlı Siteler } \\
\hline Sanal dünyalar & Secondlife, ActiveWorlds, Yoğurtistan \\
\hline Oyun paylaşımı & Miniclip, King.com \\
\hline \multicolumn{2}{|r|}{ Diğer Siteler } \\
\hline Bilgi toplayıcılar & Netvibes, Twine \\
\hline $\begin{array}{l}\text { Sosyal medya } \\
\text { izleme ve analiz }\end{array}$ & Sysomos, Ubervu \\
\hline
\end{tabular}

Kaynak: Dedeoğlu (2013)'den uyarlanmıştır.

Sosyal medya araçları içerisinden bazıları ülkemizde kullanım oranları açısından daha çok öne çıkmaktadır. Bu araçlar kısaca aşağıdaki gibi açıklanabilir:

Blog: Türkçe karşılığı ile blog kavramı, ağ günlüğü olarak ifade edilebilir. Blog olarak kullanılan sosyal medya aracındaki kullanıcılar "ses, metin ve görüntü" kullanarak bir içerik oluşturabilirler (Çelik, 2013: 5). Bloglarda insanlara çekici gelen yanın, kişilerin kendilerini ifade etme ihtiyaçları olduğu söylenebilir. Blog ile kişiler başkalarının da katılım gösterebileceği bir platform oluşturmuș olurlar. İlgi duyulan her hangi bir konuda yazı yazabilme imkânı vermesi de blogları popüler yapmaktadır (Akar, 2011: 22). Ayrıca blog siteleri kullanım kolaylığı sağladığı için de kullanıcılara çekici gelmektedir (Dilmen, 2009: 117). Sosyal medya kullanıcılarının tercih ettikleri çok çeşitte blog mevcuttur. Bu blog çeşitleri Tablo 3 'te açıklanmıştır.

Twitter: Twitter bir mikroblog türü olup, bu sistem ile kişiler özellikle anlık düşüncelerini hızlı bir şekilde paylaşabilmektedirler. Twitter sisteminde kişiler, resim ve video gibi araçları da kullanabilirler. Ayrıca herkes birbirinin paylaşımını görebilir ve yanıt verebilir. Böylece kullanıcılar hızlı ve kolay bir şekilde fikir alış verişi yapabilirler (Törenli, 2005: 46).

Forumlar: Forum siteleri, wiki ve bloglardan farklıdırlar çünkü bu sosyal medya sisteminde üyelik koşulu vardır. Forumlarda belirli bir kişinin kontrolü ve denetimi esastır ve 
bu kişi site yöneticisidir. Yönetici, sayfadaki yorumlara kendisi müdahale edebilir. Forum siteleri de her hangi bir alanda ya da konuda olabilir. Üyelik sağlayan her kullanıcı forumda duygu ve düşüncelerini paylaşabilir (Eldeniz, 2010: 25).

Tablo 3. Blog Türleri

\begin{tabular}{ll}
\hline \multicolumn{1}{c}{ Tür } & Açılama \\
\hline Kişisel Blog & $\begin{array}{l}\text { Kişilerin kendi duygun ve düşüncelerini } \\
\text { paylaştıkları blog türü }\end{array}$ \\
\hline Temasal blog & $\begin{array}{l}\text { Moda, sanat, kitap, iş, spor vb. her hangi } \\
\text { bir alanda paylaşımların yapıldığı blog }\end{array}$ \\
\hline Portföy amaçlı blog & $\begin{array}{l}\text { Belirli bir meslek kolunda iş portföyü } \\
\text { için oluşturulan blog }\end{array}$ \\
\hline Topluluk blog & Grupların yazdıkları yazıları içeren blog \\
\hline Kurumsal blog & $\begin{array}{l}\text { Kurumsal firmaların, işletmelerin ya da } \\
\text { çalışanlarının hazırladığı bloglar }\end{array}$ \\
\hline
\end{tabular}

Kaynak: Çelik (2013)'“den uyarlanmıştır.

Keskin ve Baş (2015) da yaptıkları çalışmada tüketicilerin en çok forum sitelerinden ve Facebook'dan etkilendiğini tespit etmişlerdir. 2017 verilerine göre, Türkiye'de en çok ziyaret edilen forum siteleri şu şekildedir (Uyanıkoğlu, 2017):

- Turkhackteam (üye sayıs1: 804.647)

- CHIP Online (üye sayıs1: 286,670)

- Forum TR (üye sayıs1: 4,878,886)

- WM Aracı (üye sayıs1: 64.195)

- Technopat Sosyal (üye sayıs1: 124.032)

- Webtekno (üye sayısı: 1.921)

- r10.NET (üye sayısı: 246.458)

- $\quad$ Shift Delete.Net (üye sayısı: 804.647)

- Memurlar.net

- Donanım Haber (üye sayısı: 1.722.670)

Podcastingler: Podcasting aracı, Apple'ın iPod oynatıcısının adından üretilmiş olup, ses dosyalarının mobil cihazlarda dinlenebilmesini amaçlamaktadır. Ses ve video paylaşımı ile birlikte müzik, eğlence ve diğer amaçlarla da kullanılan bir ortamdır (Karaman vd. 2008: 36). Podcasting, RSS'de olduğu gibi mobil araçlarla ses içeriklerinin iletilmesini sağlamaktadır. Önceleri eğitim amaçlı kullanılan podcasting sonradan daha çok eğlence amaçlı kullanımlara doğru yönelmiştir. İnternetten mobil araçlara yükleme yapan kişiler sonradan internet olmadan yükledikleri içeriklere ulaşabilmektedirler (Gülseçen vd., 2010: 788). Podcasting için bazı avantaj ve dezavantajlar ise Tablo 4 'te sıralanmıştır.

Tablo 4. Podcasting Avantaj ve Dezavantajları

\begin{tabular}{ll}
\hline \multicolumn{1}{c}{ Avantajlar } & \multicolumn{1}{c}{ Dezavantajlar } \\
\hline - Kullanıcılar istediği zaman & - Teknolojik altyapıyla \\
ve yerde kayıtlarına ulaşabilir & entegre olma sıkıntıları \\
- Az masraflıdır & olabilir \\
- Dijitaldir ve çevrimiçi & - Lisans anlaşmalarındaki \\
erişim vardır & zorluklar \\
- Basittir ve kullanıcı & - Akademik içeriklerde \\
dostudur & eksiklikler olması \\
& - Teknik kısıtlar olması \\
& - Öğrencilerin bu sistemin \\
& farkında olmaması \\
\hline
\end{tabular}

Kaynak: Gülseçen vd. (2010)'dan uyarlanmıştır.

Sosyal Ağ Siteleri: Sosyal ağlar için sözlük anlamı, "bir ya da daha fazla toplumsal ilişki ile birbirine bağlı bireylerin oluşturduğu" ağ olarak bir tanım gelmektedir (Özmen vd., 2011: 42). Sosyal ağlar, sosyal medya ortamları içerisinde eski bir geçmișe sahiptir. Kișiler sosyal ağlar üzerinden birbirleri ile paylaşımda ve iletişimde bulunabilmektedirler (Dilmen ve Öğüt, 2010: 239). Sosyal ağlar ya da profesyonel ağlar insanların ve kurumların arasında esnek bir etkileşime imkân verir. Sosyal paylaşım ağı olarak; "Classmates.com ve SixDegrees.com" tipik örnek sitelerdir (Özmen vd., 2010:42). Sanal ortamda etkileşimi teşvik eden sosyal ağlar, bilgi paylaşımını ve fikir alışverişini de daha kolay hale getirmektedir (Pempek vd., 2009: 228). Sosyal ağ siteleri için bazı ortak özelliklerden bahsedilebilir. Bu özellikler şu şekilde özetlenebilir (Kahraman, 2013: 57-58):

- Profiller: Kullanıcıların kendilerine ait kişisel bir profil oluşturmaları.

- Bağlantı: Kişilerin birbirine bağlanması.

- Özel mesajlaşma: Özel mesajlaşma imkanı olması.

- Açık mesaj: Herkese açık mesaj sisteminin olması.

Hagel (1997)'ye göre, sosyal ă̆ kullanıcılarının amaçlarına göre şu gruplardan bahsedilebilir (Hagel 1997'den aktaran: Özdemir vd., 2014: 59):

- Bilgi paylaşım toplulukları: Kişiler bilgi alışverişi amaciyla toplanırlar.

- İlgi toplulukları: Spesifik ilgiler doğrultusunda toplanan kişiler.

- Fantezi toplulukları: Eğlence ya da fantezi amaçlı toplanan kişiler.

- İlişki toplulukları: Duygu paylaşımı amaçlı toplananlar.

- Tartışma toplulukları: Belirli bir konuya yönelik tartışma amaçlı toplananlar

Sosyal A ̆g siteleri için Tablo 5'deki gibi bir çeşitlendirme yapilabilir.

Tablo 5. Sosyal A $\breve{g}$ Site Örnekleri

\begin{tabular}{ll}
\hline Site Türleri & Örnekler \\
\hline Sosyal siteler & MySpace, Facebook, Twitter \\
Fotoğraf paylaşım & Flicker, PhotoBucket \\
Video paylaşı & Youtube \\
Profesyonel ağ & LinkedIn, Ning \\
Wiki & Wetpaint, PBWiki \\
Blog & Blogger.com, Wordpress \\
İçerik etiketleme & MERLOT, SLoog \\
Sanal dünya & SL, Active Worlds, There, Whyville, \\
& Club Penguin, HiPiHi. \\
\hline
\end{tabular}

Kaynak: Dawley' den (2009) uyarlanmıştır (aktaran: Dal ve Dal, 2014: 147).

Facebook: M. Zuckerberg ve arkadaşlarının 2004 yılında kurduğu Facebook sistemi, günümüzde en popüler sosyal ağ sitelerinin başında gelmektedir. Önceleri, Harvard üniversitesi öğrencileri arasında kullanılan sosyal ağ, zamanla bütün dünyada kabul görmüş bir sosyal medya arac1 olmuştur (Köseoğlu, 2012: 63). Facebook, kendi içerisinde başka bağlantılara da izin vermektedir. Ayrıca Facebook üyeleri ve kullanıcıları bu ortamda rahatlıkla iletişim kurabilmektedir (Durmuş vd., 2010: 61).

Linkedln: Linkedln sitesi, 2002 yılında R. Hoffman tarafindan kurulmuştur. Çoğu sosyal medya ağlarına göre, Linkedln sitesi daha eskidir. Bu site aracılığıyla, insanlar kendi profesyonel iş ağlarını oluşturabilmektedir (Sayımer, 2008: 22). Linkedln sitesinde, kullanıcılar kendi profesyonel CV'lerini ve özgeçmişlerini yaratarak ya da ekleyerek bir kişisel profil oluştururlar. Böylece insan kaynakları 
açısından bu site büyük bir kariyer havuzu yaratmış olmaktadır. Personel ihtiyacı olan işletmeler bu siteden istihdam kaynağı sağlayabilirler (Yılmaz, 2016: 38-39). Dolayısıyla Linkedln sitesinin, kurumlar açısından özellikle insan kaynakları açısından kullanıldığı ve tercih edildiği söylenebilir. İşletmeler de Linkedln'de kendi kurumsal profillerini oluşturarak, istedikleri insan gücünü buradan kendine çekebilirler (Sevinç, 2012: 133).

Youtube: Youtube, "eğlence, müzik, belgesel, eğitim, tanıtım, reklam vb. daha birçok" video ya da görüntünün yer aldığı çok yönlü bir sosyal ağ sitesidir. Kullanıcılar kendilerine ait videoları da yükleyebilmekte ve paylaşabilmektedir (Gürsakal, 2009: 83). Youtube, 2005 yılında kurulmuş ve 2006'da Google tarafından satın alınmıştır. Youtube sitesi, videoların kullanıcılar arasında daha rahat paylaşılmasını sağlamaktadır. Kullanıcılar izledikleri her şey için yorum yazabilir, beğenisini belli edebilir ya da diğer sosyal medya ağlarında paylaşabilir (Ateş, 2015). "Türkiye YouTube Kullanıcı Profili Araştırması 2016"'nın sonuçlarına göre, YouTube kullanımı ile ilgili şu bilgilere rastlanmıştır (Ferah, 2016):

- Youtube'u izleyen kişilerden \%87'si birden fazla kez bu siteyi ziyaret etmekte

- Bu kişilerin \%36'sı günde 5 defadan fazla izleme yapmaktadır, Ayrıca YouTube'u her gün ziyaret edenlerin \%88'i evden ve \%30'u ise ev veya okuldan bu siteyi ziyaret etmektedir.

Instagram: Instagram özellikle mobil cihazlar için geliştirilmiştir ve fotoğraf paylaşımının değişik araçlarla değiştirilerek ve yenilenerek paylaşılmasını hedefleyen bir sosyal medyadır. M. Krieger ve K. Systrom tarafindan geliştirilmiş bir uygulamadır ve birçok sosyal medya aracı ile de uyumlu olarak çalışabilmektedir. Ücretsiz bir uygulama olup, 2010 tarihinde kurulmuştur (Ateş, 2017).

Vikipedi: Vikipedi, küresel boyutta kullanılabilen, özgür ve ortaklaşa bilgilerden oluşturulmuş, farklı dünya dillerinde olabilen bir online ansiklopedi şeklindedir. Sürekli yenilenmeye ve güncellenmeye elverişli bir wiki teknolojisi ürünüdür (Bostanc1, 2010: 64).

Sosyal medya ortamları, kullanıcıların, tüketicilerin ve grupların kendi paylaşımlarını katmaları ve aktif katılımlarını devam ettirmeleri ile geleneksel medya ortamlarından oldukça farklıdırlar (Akar, 2011: 65). Diğer yandan, Sütçü (2014)'ün habercilik alanı için belirttiği yenilikler aşağıda sıralanmıştır (Sütçü 2014'den aktaran: Sütçü ve Bayrakç1, 2014: 42):

- Haber kaynağına ulaşmada kolaylık sağlanması

- Haberin yazılmasından başlamak üzere hedef gruplara ulaşıncaya kadar yerine getirilen faaliyetlerde hız kazanma,

- Haberlerin okuyucularında kanaat önderlerine ulaşma ve sayıda artış sağlanması

Sosyal medyanın getirdiği yenilikler açısından; geleneksel medyaya göre daha fazla kullanıcıya ulaşması, kullanıcıların da paylaşıma geçebilmesi ve çok yönlü iletişimin olması söylenebilir. Sosyal medya ortamlarında içerikleri herkes görebilir ve kişiler çoğunlukla yorum yapabilir durumdadır (İli, 2013: 7). Sosyal medya halkla ilişkiler açısından da faydalı bir araç niteliğindedir. Halkla ilişkiler faaliyetinde hedef kitleye ulaşmak ve mesaj iletmek önemlidir. Sosyal medya ortamlarının halkla ilişkiler faaliyetleri için kullanımı ile işletmeler daha etkin şekilde hedef kitlere ulaşmaya başlamışlardır. Sosyal medya ortamlarındaki iletişimin çok yönlü olması sayesinde duygu ve düşünceler işletmeler ve tüketiciler arasında paylaşılmaktadır (Çelik, 2012: 4-5).

Sosyal medyanın sağladığı faydaların yanı sıra bazı eleştiriler de söz konusudur. Bu eleştirilerden öne çıkanları (yeni nesil için Yrd. Doç. Dr. Rıdvan Üney'den alıntılarla) Tablo 6'da özetlenmiştir (Hürriyet, 2016).

Tablo 6. Sosyal Medyanın Olumsuz Yönleri

Sosyal medyanın yeni nesle yönelik olumsuzlukları:

Çocuklarda ve gençlerde bazı kimlik problemleri yaratma

Çocuklarda ve gençlerde mahremiyet duygusunu engelleme ve bu duygunun gelişimini olumsuz etkileme

Sosyal medya ortamlarında çocuk ve ergen bireylerde kandırılma durumlarının yaşanması

Sosyal medyada zararlı paylaşım, içerik ve davranışlarda bulunan kişiler için yasal açık olması

Genç bireylerde popüler olma isteğini şiddetlendirmesi ve mutsuzluk getirmesi

Paylaşılan fotoğraflar ile gençlerin kendilerini kötü duruma düşürmesi

Toplumda uzaklaşma yaratması

Hareketsizlik sonucu kilo alımı gibi sorunlar yaratması

Konuşma yerine yazmaya ağırlık veren genç topluluklar yaratmas1

Gerçek hayattan uzaklaşma

Kaynak: Hürriyet (2016)'dan uyarlanmıştır.

Sosyal medyanın yarattı̆̆ı bazı olumsuzluklar şu şekilde de açıklanabilir (Hapat, 2016):

- “İnsanlar = Ürün” olarak bir durumun ortaya çıkması, çünkü bütün sosyal medya ortamları için insanlar bir ürün kaynağıdır,

- Azalan gizlilik durumu olması, sosyal medyadaki paylaşım güdüsünün insanları her şeyi paylaşmaya yönlendirmesi ve gizliliğin azalması,

- Sağlık sorunlarının artması, özellikle uzun süre hareketsiz kalan ve mesaj atan kişilerde "hypernetworking" gibi bir durumun ortaya çıkması,

- Soyutlanma durumunun olması, yüz yüze iletişimin geride kalması, sosyal medyanın kişilerde aşırı kullanımı sonucunda beyinde farklı etkilerin olması,

- Diğer sorunlar olarak ise: dil bilgisinin bozulması, yanlış bilgilerin gerçek algılanması, sapkın düşüncelerin yayılması, kimlik hırsızlıkları, sanal zorbalık vb. sayılabilir.

Sosyal medya hem olumlu hem de olumsuz yanlariyla büyümeye ve gelişmeye devam eden teknolojik bir sistem olup, her geçen gün kullanıcı sayısı gittikçe artan önemli bir pazar haline gelmektedir. Dolayısıyla sosyal medya ile ilgili her alanda daha çok çalışma olacağı söylenebilir. Diğer yandan her bilim alanı kendi konusuna sosyal medyayı dahil ederek yeni bulgular ile literatüre katkıda bulunacaktır. Bu çalışmada da pazarlama alanının önemli bir parçası olan tüketici davranışları bağlamında sosyal medyanın üniversite öğrencilerinin satın alma davranışlarına nasıl bir etkide bulunabileceği kavramsal çerçevede incelenmiştir. 


\section{Yöntem}

Son zamanlarda, sosyal medyanın tüketici davranışlarına olan etkisi literatürde giderek artan bir araştırma konusu haline gelmiştir. Özellikle yeni nesil jenerasyonun davranışlarının belirlenmesi ve teknoloji çağının getirdiği etkileri ortaya çıkarmak hem literatür hem de pratik hayat için önemli katkıları olan çalışmalar arasındadır. $\mathrm{Bu}$ bağlamda çalışmanın amacı tarama modeli yönteminden faydalanarak, sosyal medyanın üniversite öğrencilerinin satın alma davranışlarına etkisini incelemektir. Tarama modeli kullanılan çalışmalar betimleyici bir araştırma yöntemi kullanmaktadır. Dolayısıyla çalışmanın bulgu ve yorumları niteliksel özellik taşımaktadır. Çalışmada istatistiki analiz ve yöntemler kullanılmayacaktır. Çalışmada konu ile ilgili başlıca tez, makale ve bildiri gibi güncel ikincil veri kaynaklarının taranması ve gerekli bilgilerin özetlenmesi hedeflenmiştir. Böylece literatürdeki mevcut bilgilerin daha sistematik hale getirilmesi düşünülmüştür. Diğer yandan çalışmada sadece Türkiye'deki son zamanlarda yapılan sosyal medya ve üniversite öğrencilerinin satın alma alışkanlıkları ile ilgili çalışmalar yer aldığından, bu durum da önemli bir kısıt oluşturmaktadır.

\section{Sosyal Medya ve Üniversite Öğrencilerinin Satın Alma Davranışları ile ilgili Yapılmış Çalışmaların İncelenmesi}

Bu bölümde incelemek üzere Türkiye'de son zamanlarda yapılan konumuzla ilgili bazı çalışmalar ele alınmıştır. Yapılan incelemeler sonucunda aşağıdaki bulgulara ulaşılmıştır:

İşlek (2012), yaptığı tez çalışmasında "Sosyal medyanın tüketici davranışlarına etkileri: Türkiye'deki Sosyal medya kullanıcıları üzerine bir araştırma" konusunu çalışmıştır. Bu tezde anket uygulaması ile 845 sosyal medya kullanıcısına ulaşılmış ve bu kullanıcılardan alınan yanıtlar analiz edilmiştir. Kullanıcılar incelendiğinde sosyal medyada çoğunlukla genç nüfus dediğimiz 18 yaştan 35'e kadarki yaş grubunun ağırlıklı olduğu görülmüştür. Özellikle 18-25 yaş grubu, genç nüfus örneklemde daha çok yer almıştır. Anket yapılan kişilerin çoğunlukla üniversite eğitimine sahip olduğu ve çoğunlukla erkek cinsiyetinde olduğu da görülmüştür. Diğer önemli bir bilgi ise demografik yap1 içerisinde çoğunluğun öğrenci olmasıdır. Çalışma sonucunda elde edilen bilgilere göre, İşlek (2012), sosyal medya araçlarının özellikle ürün satın almadan önce araştırma amaçlı bu medyayı kullandıklarını belirtmiştir. Ayrıca hedef kitleye ulaşmada sosyal medyanın önemli olduğu, tüketicilerin bu medya aracına da bilgi amaçlı olarak önem verdiği görülmüştür. İşlek (2012), yaptığı hipotez testleri sonucunda da; hem sosyal medyanın kullanımının satın alma öncesi davranışı ile hem de satın alma sonrası davranış ile pozitif ilişkide olduğu bulunmuştur. Sosyal medyada satın alma davranışı ile satın alma sonrası davranış arasında da pozitif bir ilişki bulunmuştur.

Elbaşı (2015), bir tez çalışması ile sosyal medyada kullanıcı motivasyonu ve üniversite öğrencilerinin pazarlama algısına yönelik bir araştırma yapmıştır. Çalışmada 400 kişiye ulaşılmış ve 348 adet anket formu analizi ile çeşitli sonuçlara varılmıştır. Çalışmasında İstanbul'da 18 yaş üzeri üniversite öğrencilerinden ve sosyal medya araçlarından en az 1 tanesini kullananlar örnekleme alınmıştır. Çalışma sonucunda, sosyal medya kullanıcı motivasyonunun üniversite öğrencilerinin sosyal medya pazarlama algıs1 üzerinde etkili bir değişken olduğu yönünde çıktılar elde edilmiştir. Ayrıca sosyal medya araçlarındaki eğlendirici faktörlerin de sosyal medyadaki pazarlamanın daha eğlenceli algılanmasını sağladığı belirtilmiştir. Diğer yandan, sosyal medya pazarlamasının rahatsız edilmesinin, sosyal medya pazarlama faaliyetlerinin ihtiyaca yönelik olmaması olabileceği belirtilmiştir. Hedef kitleye ulaşma bakımından firmaların sosyal medyada dikkatli olmaları önerilmiştir. Dolayısıyla, sosyal medyadaki pazarlama faaliyetlerinin rahatsız edici değil; eğlendirici olması gerektiği önerilmiştir.

Bostancı (2010), tezinde üniversite öğrencilerinin sosyal medya kullanım alışkanlıkları üzerine bir konuyu çalışmıştır. Çalışmasında Gazi Üniversitesi ve Erciyes Üniversitesinden İletişim Fakültesinde öğrenim gören üniversite öğrencilerine anket uygulaması yapılmıştır. Çalışmada 380 öğrenciye anket uygulanmış ve sonuçlar analiz edilmiştir. $\mathrm{Bu}$ çalışmada da çoğunlukla erkek öğrencilere rastlanmaktadır. Çalışmada 20-23 yaş arası gençlerin ağırlıklı olduğu görülmüştür. Öğrencilerin çoğunluğunun her gün internete bağlandığı ve en çok sosyal medya araçlarını kullandıkları görülmüştür.

Solmaz vd. (2013), yaptıkları çalışmada sosyal medya kullanımını araştırmışlar ve Selçuk Üniversitesi İletişim Fakültesi öğrencileri üzerine bir anket uygulaması yapmışlardır. Çalışmalarında 500 öğrenciye anket yapılmıştır. Çalışma sonucunda üniversite öğrencilerinin çoğunluğunun sosyal medyayı yoğun kullandığı, eğlence, boş zaman geçirme, mesaj gönderme ve iletişim amaçlı kullandığı görülmüştür. Öğrencilerin \%55'nin sosyal medyada marka satın alma davranışı sergiledikleri görülmüştür.

Olgun (2015), yaptığı çalışmada sosyal medyanın tüketici satın alma davranışına etkisini araştırmıştır. çalışmasında İstanbul Aydın Üniversitesi öğrencilerine anket uygulaması yapılmıştır. 250 kadın ve 250 erkek şeklinde yüz yüze anket uygulaması yapılmıştır. Çalışmasında yaş olarak çoğunlukla 21-23 yaşın ağırlıklı olduğu görülmüştür. Öğrencilerin \%79'unun ürün satın alma öncesi sosyal medya araştırdıkları görülmüştür (Olgun, 2015: 504).

Baycan (2017), yaptığı çalışmada Y kuşağının sosyal medya ve satın alma davranışlarını araştırmıştır. 1980-2000 arası doğanların Y kuşağı olarak alındığı çalışmada, sosyal medyayı en çok kullanan kesimin bu kuşak olduğu belirtilmiştir. Bu kuşağın bilinçli tüketici olduğu sosyal medyada araştırma yaptıkları vurgulanmış ve sosyal medyada pazarlama açısından bu kitle ile çift yönlü iletişimin öneminden bahsedilmiştir. Diğer çalışmalara benzer şekilde bu çalışmada da satın alma öncesi ve sonrasında sosyal medyanın kullanıldığı belirtilmiştir.

İstanbul Bilgi Üniversitesi, İletişim Fakültesi ve Pazarlama 3.0 işbirliğinde, Sosyal Medyada Markalar Araştırma Raporunda (Mayıs 2017), 290 kişiden anket formu toplayarak bazı sonuçlar çıkarmıştır. Çalışmanın anket uygulamasına, Türkiye, KKTC, Almanya, ABD, Amerika, İngiltere ve Azerbaycan gibi ülkelerden katılım olmuştur. Çalışma sonuçlarına göre, çoğunluğun 26-35 yaş grubu ve 18-25 yaş olduğu görülmüştür. Ayrıca ankete katılanların çoğunluğunun üniversite öğrencisi ya da lisans mezunu 
olduğu görülmüştür. Markaların takip edildiği ve satın alma kararını sosyal medyanın etkilediği görülmüştür.

Küçükali (2016), yaptı̆̆ $\quad$ çalışmada, üniversite öğrencilerinin sosyal medya kullanma alışkanlıklarına yönelik bir araştırma yapmıştır. Çalışmasında Atatürk Üniversitesi İIBF Çalışma Ekonomisi ve Endüstri ilişkileri bölüm öğrencilerinden birinci ve ikinci öğretimdeki öğrencilere anket uygulaması yapılmıştır. 215 öğrenciden elde edilen bilgiler analiz edilmiştir. Çalışma sonucunda öğrencilerin çoğunlukla 19-21 yaş arasında olduğu görüşmüştür. Öğrencilerin çoğunluğu her gün internete giriş yapmakta ve cep telefonunu çoğunlukla kullanmaktadırlar.

Akkaya (2013), yaptığı doktora tezinde sosyal medya reklamlarının tüketici algı, tutum, davranış ve satın almaya etkileri üzerine bir konu çalışmıştır. Çalışmasında Marmara bölgesinde bulunan çeşitli üniversitelerin öğrencilerinden anket uygulaması yapmıştır. 1052 anket formu analize uygun bulunmuştur. Çalışmasında çoğunluğun yaşının 19-22 yaş aralığında olduğu ve sosyal ağları günlük olarak 7 saatten fazla ziyaret ettikleri görülmüştür. Çalışma sonucunda, öğrencilerin sosyal medya reklamlarını beğendikleri ve ürün ihtiyacı olduğunda satın aldıkları görülmüştür. Çalışmada sosyal medya reklamlarının satın alma niyeti üzerinde etkisi olduğu belirtilmiştir.

Gençlik ve Spor Bakanlığı'nın (2013) yaptığı çalışmada "Gençlik ve sosyal medya araştırma raporu" şeklinde bir araştırma bulunmaktadır. Bu raporda 15-29 yaş arası gençler araştırılmıştır. İnternet kullanıcılarının çoğunluğunun sosyal medya kullanıcısı olduğu görülmüştür. Çoğunluğun günde en az bir kere sosyal medyaya bağlandığ 1 ve sosyal medyada aktif oldukları görülmüştür.

Özcan ve Akıncı (2017) yaptıkları çalışmada, sosyal medya ve üniversite öğrencilerinin satın alma davranışları konusunu araştırmışlardır. Çalışmalarında Akdeniz Üniversitesi Turizm Fakültesi (Konaklama işletmeciliği ve Seyahat işletmeciliği bölüm) öğrencilerinden 250 kişiye ulaşmışlar ve anket uygulaması yapmışlardır. Çoğunluğun 20-23 yaş aralığında olduğu görülmüştür. Haftada sosyal medyayı 2 ve 6 saat arası kullananların ağırlıklı olduğu görülmüştür. Satın alma davranışı açısından, öğrencilerin memnun kalmadıkları ürünleri sosyal medyada paylaştıkları ama memnuniyetlerini pek fazla paylaşmadıkları görülmüştür. Ayrıca çalışmada satın alma öncesi bilgi kaynağı olarak sosyal medyanın önemi belirtilmiştir.

Çağlıyan vd. (2016) yaptıkları çalışmada, üniversite öğrencilerinin sosyal medyaya göre satın alma davranışlarının etkilenip etkilenmediği yönünde bir araştırma yapmışlardır. Çalışmalarında Selçuk üniversitesi İIBF işletme bölüm öğrencilerine anket yapılmıştır. 104 anket formu toplanmıştır. Çoğunluğun 21-23 yaş aralığında olduğu görülmüştür. Ayrıca çoğunluğun sosyal medyada 36 saat geçirdikleri görülmüştür. Öğrencilerin satın alma davranışları ile sosyal medya reklamları arasında ise pozitif korelasyon ilişkisi görülmüştür. Bunun anlamlı etkisi ise regresyon analizi ile test edilmiş ve çalışma sonucunda sosyal medyanın üniversite öğrencilerinin satın alma davranışları üzerinde anlamlı etkisi olduğu belirtilmiştir.

Çetin ve Kumkale'nin (2016) yaptıkları çalışmada sosyal medya kullanımı ve satın alma niyeti arası ilişkiler araştırılmıştır. Çalışmalarında Edirne-Keşan'da üniversite öğrencilerine anket uygulaması yapılmıştır. Toplamda 191 anket formu elde edilmiş ve analiz edilmiştir. Çalıșmada faydacı motivasyon da araştırılmıştır. Çalışma sonucunda, sosyal medya kullanım düzeyinin satın alma niyetine etki etmesinde uygunluk değişkeninin (kısmen), bilgi yeterliliği, ürün seçimi ve özelleştirilmiş reklamların (tam) aracılık ettikleri belirtilmiştir.

Sosyal medya kullanıcıların ağırlıklı olarak genç olmaları çalışmalara da yansımaktadır. Çalışmaların çoğunda üniversite öğrencileri yaş grupları Tablo 7'de gösterilmektedir.

Tablo 7. Sosyal Medya'y1 S1k Kullanan Üniversite Öğrencilerinin Yaşları

\begin{tabular}{ll}
\hline Araştırmacılar & $\begin{array}{l}\text { Sosyal Medya } \\
\text { Araştırmada en çok } \\
\text { rastlanan yaş grubu }\end{array}$ \\
\hline Çağlıyan vd. (2016) & $21-23$ yaş çoğunluk \\
Özcan ve Akıncı (2017) & $20-23$ yaş çoğunluk \\
Gençlik ve Spor Bakanlığı (2013) & $15-29$ yaş çoğunluk \\
Akkaya (2013) & $19-22$ yaş çoğunluk \\
Küçükali (2016) & $19-21$ yaş çoğunluk \\
İstanbul Bilgi Üniversitesi (2017) & $18-25$ yaş ve 26-35 yaş \\
Olgun (2015) & çoğunluk \\
Bostanc1 (2010) & $21-23$ yaş çoğunluk \\
İşlek (2012) & $20-23$ yaş çoğunluk \\
& $18-25$ yaş çoğunluk \\
\hline
\end{tabular}

Tablo 7'de görüldüğü üzere, son zamanlarda yapılan çeşitli araştırmalarsa sosyal medya kullanıcılarının çoğunlukla 18 'den başlayan ve en fazla 25 yaşa kadarki üniversite öğrencilerinin olduğu söylenebilir. Yapılan anket çalışmalarında çoğunlukla bu yaşlarda olduğu görülmüştür.

\section{Sonuç ve Değerlendirme}

Günümüz bilgi çağında özellikle genç nüfusun ağırlıklı olması ve bu kitlenin yoğun olarak teknoloji ile ilişkili olmaları sosyal medyanın pazarlama açıcından önemini arttırmaktadır. Dolayısıyla, dünya çapında sosyal medyanın tüketici davranışlarına etkisi üzerine yapılan çalışma ve araştırmalar da artmıştır. Bu çalışmada da sosyal medyanın üniversite öğrencilerinin satın alma davranışları üzerine etkisi konusu tarama modeli yardımıyla incelenmiştir. Çalışmada sadece Türkiye'de son zamanlarda yapılan çalışmalar incelenmiş ve bir yargıya varılmaya çalışılmıştır. Dolayısıyla, çalışmanın önemli bir kısıtı niteliksel çalışma olması ve tarama yönteminin Türkiye'deki çalışmaların belirli bir kısmını kapsamasıdır. Çalışmada incelediğimiz araştırmacıların buldukları bazı temel sonuçlar ve öneriler aşağıdaki gibi özetlenebilir (Gençlik ve Spor Bakanlığı, 2013; Çağliyan vd., 2016; Çetin ve Kumkale, 2016; Özcan ve Akıncı, 2017; Akkaya,2013; Solmaz vd., 2013; Elbaşı, 2015; İşlek, 2012; Olgun, 2015; Baycan, 2017; İstanbul Bilgi Üniversitesi ve Pazarlama 3.0, 2017):

(i) Türkiye'de son zamanlarda yapılan "sosyal medya ve gençlerin ya da üniversite öğrencilerinin satın alma davranışları" konulu araştırmalara göre; sosyal medyanın kullanıcıları arasında büyük çoğunluğu üniversite öğrencileri oluşturmaktadır. Çalışma kapsamında incelenen araştırmalara göre sosyal medyanın pazarlama ya da reklam faaliyetlerinin zaman zaman rahatsız edici olduğu görülmektedir. Eğlence faktörünün arttırılması ile bu durumun giderilmesi gerektiği ve reklamların ya da diğer 
pazarlama faaliyetlerinin daha cazip hale getirilmesi gerektiği önerilmektedir.

(ii) Çalışma kapsamında incelenen araştırmalara göre, sosyal medyanın üniversite öğrencilerinin satın alma öncesi davranışı etkilediği ve ilișkili olduğu görülmüştür. Diğer bir deyişle, sosyal medya ortamları da bilgi kaynağı olarak kullanılmaktadır.

(iii) İncelenen çalışmalara göre, sosyal medyanın üniversite öğrencilerinin satın alma sonrası davranış ve tutumlarını etkilediği yönünde sonuçlar görülmüştür. Diğer bir deyişle, gençler ya da öğrenciler memnuniyetlerini az olmakla beraber, memnuniyetsizliklerini sosyal medya ortamlarını paylaşmaktadır.

(iv) İncelenen çalışmalarda, üniversite öğrencilerinin sosyal medyayı yoğun kullandıkları görülmüştür. Hemen hemen her gün sosyal medya ortamlarına giriş yaptıkları günün belirli saatlerini bu ortamlarda geçirdikleri görülmüştür.

(v) İncelenen çalışmalarda, sosyal medyanın üniversite öğrencilerinin satın alma davranışlarını etkilediği görülmüştür.

(vi) Türkiye'de artan genç nüfus kitlesi dikkate alındığında, sosyal medyanın pazarlama aracı olarak kullanımının da arttırılması, markalar açısından faydalı olabilir.

(vii) Teknolojinin devamlı olarak yenilenmesi ve internetin daha ulaşılabilir hale gelmesi ile sosyal medya ortamlarında reklamlara ağırlıklı olarak yer verilebilir.

(viii) Sosyal medya ortamlarında ağırlıklı olarak genç nüfusa yönelik mal ya da hizmetlerin pazarlanması yapılabilir.

(ix) Sosyal medyadaki reklam ya da pazarlama kampanyalarında eğlence unsuruna önem verilebilir ve rahatsız edici reklam kampanyalarından kaçınılmalı.

(x) İnternet ortamında çoğunlukla sosyal medya ortamı ya da ağı olarak adlandırılan yerlerde pazarlama faaliyetlerine ağırlık verilebilir.

(xi) Çalışma kapsamında incelenen araştırmalara göre sosyal medyanın üniversite öğrencilerinin satın alma niyetleri ya da tutumları üzerinde olumlu yönde etkisi olduğu görülmüştür.

(xii) Satın alma öncesi sosyal medyanın bir bilgi kaynağ olarak kullanıldığ 1 göz önüne alınırsa, marka ya da firmaların yeni ürünlerini özellikle sosyal medya ortamlarında tanıtmaları faydalı olabilir.

(xiii) Üniversite öğrencileri bir ürünle ilgili memnuniyetsizliklerini sosyal medya ortamlarında paylaştığ 1 için müşteri hizmetleri ya da müşteri şikayet noktaları daha etkin olabilir ya da sosyal medya ortamları aracılığıyla tüketiciye ulaşılabilir.

\section{Kaynakça}

Akar, E. (2011). Sosyal Medya Pazarlamast: Sosyal Web'te Pazarlama Stratejileri. Ankara: Efil Yayınevi.

Akkaya, D. T. (2013). Sosyal Medya Reklamlarında Tüketici Algılarının Tutum, Davranış ve Satın Alma Niyeti Üzerine Etkisi. Doktora Tezi. Edirne: Trakya Üniversitesi.

Aksoy, R. (2006). Internet Ortaminda Pazarlama. Ankara: Seçkin Yayıncılık.

Aktaş, C. (2007). İnternet'in Gazeteciliğine Getirdiği Yenilikler. Selçuk Illetişim, 5(1), 30-41.
Ateș, S. (2015). YouTube Nedir?, Nasıl Kullanılır?, Ne İșe Yarar?. (Erişim:01/01/2018), http://bilgihanem.com/ youtube-nedir-nasil-kullanilir/

Ateş, S. (2017). Instagram Nedir? Nasıl Kullanılır? Ne Ișe Yarar?. (Erişim: 01/01/2018), http://bilgihanem.com/ instagram-nedir-nasil-kullanilir/

Aydede, C. (2006). Sanal Ortam Günlükleriyle Blog Çăğ. İstanbul: Hayat Yayınları.

Başhan, F. (2011). Internetin Çeşitli Yönleriyle Türk Toplumunca Benimsenmesi: Karaman Örneği. Yüksek Lisans Tezi. Karaman: Karaman Oğlu Mehmet Bey Üniversitesi.

Baycan, P. (2017). Y Kuşağının Satın Alma Davranışları Üzerinde Sosyal Medyanın Etkisi. İstanbul Ticaret Üniversitesi D1ş Ticaret Enstitüsü. Working Paper Series. (Erişim: 01/01/2018), http://ticaret.edu.tr/uploads /dosyalar/921/Y\%20Ku\%C5\%9Fa\%C4\%9F\%C4\%B1n $\%$ C4\%B1n\%20Sat\%C4\%B1n\%20\%20Alma\%20Davra n\%C4\%B1\%C5\%9Flar\%C4\%B1\%20\%C3\%9Czerinde $\% 20$ Sosyal\%20Medyan\%C4\%B1n-53.pdf

Beceren, Ö. (1997). Internete Genel Bir Baklş Ve Internette Web Sayfası Açan Türk Firmalarının Web Sayfası Açma Ve Interneti Kullanma Maksatlarının Tespitine Yönelik Bir Pilot Araştırma. Yüksek Lisans Tezi, İstanbul: İstanbul Üniversitesi.

Bostanc1, M. (2010). Sosyal Medyanın Gelişim Ve İletişim Fakültesinde Ögrrencilerinin Sosyal Medya Kullanım Alışkanlıkları. Yüksek Lisans Tezi. Kayseri: Erciyes Üniversitesi.

Bozkurt, İ. (2006). İletişim Odakl Pazarlama. İstanbul: Kapital Medya Hizmetleri.

Çağlıyan, V., Işıklar, Z. E., \& Hassan, S. A. (2016). Üniversite Öğrencilerinin Satın Alma Davranışlarında Sosyal Medya Reklamlarının Etkisi: Selçuk Üniversitesi'nde Bir Araştırma. Selçuk Üniversitesi Sosyal ve Teknik Araştırmalar Dergisi, 11. 43-56.

Çelik, M. (2013). Hızlı Tüketim Ürünlerinde Sosyal Medya Kullanımı İle Marka Konumlandırılması İstanbul Şehir Üniversitesi. Yüksek Lisans Bitime Projesi. İstanbul: İstanbul Şehir Üniversitesi.

Çetin, O. I., \& Kumkale, İ. (2016). Sosyal Medya Kullanım Düzeyi ve Satın Alma Niyeti Arasındaki İlişkide Faydacı Motivasyonun Araci Etkisi. Balkan and Near Eastern Journal of Social Sciences, 02(04), 90-101.

Dal, N. E., \& Dal, V. (2014). Kişilik Özellikleri Ve Sosyal A ğ Sitesi Kullanım Alışkanlıkları: Üniversite Öğrencileri Üzerine Bir Araştırma. Mehmet Akif Ersoy Üniversitesi Sosyal Bilimler Enstitüsü Dergisi, 6(11), 144-162.

Dedeoğlu, N. (2013). Sosyal Medya Bă̆ımlılı̆̆ı. (Erişim:01/01/2018), https://nurdedeoglu.wordpress .com/2013/06/16/260/

Dilmen, N. E. (2009). Yeni Medya Kavramı Çerçevesinde İnternet Günlükleri-Bloglar ve Gazeteciliğe Yansımaları. Marmara Üniversitesi Iletişim Fakültesi Dergisi, 12, 113-122. 
Dilmen, N. E., \& Öğüt, S. (2010). Sosyalleşmenin Yeni Yüzü: Sosyal Paylaşım Ağları. (Erişim: 01/01/2018), http://www.sertacogut.com/blog/wp-content/uploads /2010/05/Ogut-Dilmen-Sosyalle\%C5\%9Fmenin-YeniY\%C3\%BCz\%C3\%BC-Sosyal-Payla\%C5\%9F\% C4\%B1m-A\%C4\%9Flar\%C4\%B1.pdf

Durmuş, B., Yurtkoru, S., Ulusu, Y., \& Kılıç, B. (2011). Facebook'tayız: Sosyal Paylaşım Ağlarının Bireylere ve İsletmelere Yönelik Incelemesi: Facebook Üzerine Bir Araştırma. İstanbul: Beta Yayınları.

Egegen. (2017). Sosyal Medya Nedir?. (Erişim: 01/01/2018), https://egegen.com/blog/sosyal-medya-nedir/

Elbaş1, G. Y. (2015). Sosyal Medyada Pazarlama: Sosyal Medya Kullanıc Motivasyonunun Üniversite Öğrencilerinin Sosyal Medya Pazarlama Algısına İlişkin Bir Uygulama. Yüksek Lisans Tezi. İstanbul: İstanbul Ticaret Üniversitesi.

Eldeniz, L. (2010). İkinci Medya Çağında İnternet (Der. F. Aydoğan \& A. Akyüz), İkinci Medya Çă̆ı'nda Etkileşimin Rolü ve Web 2.0. İstanbul: Alfa Basın Yayın Dağıtım.

Ergin, E. E. (2015). Sosyal Medyada Reklam Kullanımı Örneği Olarak Yerli Reklamların Incelenmesi. Yüksek Lisans Tezi. İstanbul: İstanbul Kültür Üniversitesi.

Ferah, A. B. (2016). YouTube'un Türkiye kullanıcı profili araştırması. (Erişim:01/01/2018), https://webrazzi.com /2016/10/05/youtubeun-turkiye-kullanici-profiliarastirmasi/

Gençlik ve Spor Bakanlığı (2013). Gençlik ve sosyal medya araştırma raporu. Ekim 2013. Yönetici özeti. (Erişim: 01/01/2018), https://leventeraslan.files.wordpress. com/2015/09/genclik-sosyalmedyayonetici-ozeti.pdf.

Gülseçen, S., Gürsul, F., Bayrakdar, B. ,Çilengir S., \& Canım, S. (2010). Yeni Nesil Mobil Öğrenme Aracı: Podcast. Akademik Bilişim'10 - XII. Akademik Bilişi̇m Konferans1 Bildirileri. Muğla, Türkiye, 795-800.

Gün, S. F. (1999). Bütünleşik Pazarlama Iletişiminde Elektronik Reklamcılık ve Uygulamaları. İstanbul: Tüm Ofset Yayıncilık.

Gürsakal, N. (2009). Sosyal Ă̆ Analizi. Bursa: Dora Yayıncilik.

Hapat, E. B. (2016). Sosyal Medya ve Olumsuz Etkileri. (Erişim: 01/01/2018), http://vizyonered.com/genel/ sosyal -medya-ve-olumsuz-etkileri/

Hürriyet. (2016). Sosyal medyanın faydalarl ve zararlarl, İHA. (Erişim: 01/01/2018), http://www.hurriyet.com.tr /sosyal-medyanin-faydalari-ve-zararlari-40194571

İstanbul Bilgi Üniversitesi (2017). Sosyal Medyada Markalar Araştırma Raporu, Mayıs 2017. (Erişim: 01/01/2018), http://www.pazarlama30.com/wpcontent/uploads/2017/06/SOSYAL_MEDYADA_MAR KALAR_ANKET\%C4\%B0_ANAL\%C4\%B0Z\%C4\% B0c6d927a5f83a2e4f409990f82e956d9f6483e4f8.pdf.

İşlek, M. S. (2012). Sosyal Medyanın Tüketici Davranışlarına Etkileri: Türkiye'deki Sosyal Medya
Kullanıcıları Üzerine Bir Araștırma. Yüksek Lisans Tezi. Karaman: Karamanoğlu Mehmetbey Üniversitesi.

Kahraman, M. (2013). Sosyal Medya 101 2.0. İstanbul: MediaCat Yayınlar1.

Karaman, F. (2010). Işletmelerde Motivasyon ve Verimlilik. İstanbul: Etap Yayınevi.

Keskin, S., \& Baş, M. (2015). Sosyal Medyanın Tüketici Davranışları Üzerine Etkisinin Belirlenmesi. Gazi Üniversitesi IIIBF Dergisi, 17(3), 51-69.

Köseoğlu, Ö. (2012). Sosyal ağ sitesi kullanıcılarının Motivasyonları: Facebook üzerine bir araştırma. Selçuk İletişim, 7(2), 58-81.

Küçükali, A. (2016). Üniversite Öğrencilerinin Sosyal Medya Kullanımı: Atatürk Üniversitesi Örneği. Bartın Üniversitesi I.I.'B.F. Dergisi, 7(13), 531-546.

Mestçi, A. (2013). Internette Reklamcılık. İstanbul: Pusula Yayıncilık.

Olgun, B. (2015). Sosyal Medyanın Tüketici Satın Alma Davranışları Üzerindeki Etkisi. Gümüşhane Üniversitesi Sosyal Bilimler Elektronik Dergisi, 12, 484-507.

Öncel, Ü. (2012). Sosyal medyanın kısa tarihi [infografik]. (Erişim: 01/01/2018), https://webrazzi.com/2012/10/22/ sosyal-medyanin-kisa-tarihi-infografik/

Özcan, B. \& Akıncı, Z. (2017). Sosyal Medyanın Üniversite Öğrencilerinin Tüketici Davranışları Üzerinde Etkisi: Turizm Fakültesi Örneği. Süleyman Demirel Üniversitesi Vizyoner Dergisi, 8(18), 141-154.

Özdemir, S. S., Özdemir, M., Polat, E., \& Aksoy, R. (2014). Sosyal Medya Kavramı Sosyal Medya Kavramı Ve Sosyal A $\breve{g}$ Sitelerinde Yer alan Online Reklam Uygulamalarının İncelenmesi. Electronic Journal of Vocational Colleges, 4(4), 58-64.

Özel, M. (2012). Öğrencilerin Sosyal Medya Kullanımını ve Üniversitelerde Dijital Pazarlama Iletişimi Uygulamalarını Belirlemeye Yönelik Bir Araştırma. Yüksek Lisans Tezi. İstanbul: Beykent Üniversitesi.

Özmen, F., Aküzüm, C., Sünkür, M., \& Baysal, N. (2011). Sosyal Ăg Sitelerinin Ĕ̈itsel Ortamlardaki İşlevselliği. 6 th International Advanced Technologies Symposium (IATS'11), Elazığ, Turkey. (Erişim: 01/01/2018), http://web.firat.edu.tr/iats/cd/subjects/instructional/ite9.pdf

Pempek, T. A., Yermolayeva, Y. A., \& Calvert, S. L. (2009). College Students Social Networking Experiences on Facebook. Journal of Applied Developmental Psychology, 30 (3), 227-238.

Sayımer, İ. (2008). Sanal Ortamda Halkla İlişkiler. İstanbul: Beta Yayınları.

Sevinç, S. S. (2012). Pazarlama Illetişiminde Sosyal Medya. İstanbul: Optimist Yayınlar1.

Solmaz, B., Tekin, G., Herzen, Z., \& Demir, M. (2013). İnternet ve Sosyal Medya Kullanımı Üzerine Bir Uygulama. Selçuk İletişim, 7(4), 23-32.

Sütçü, C. S., \& Bayrakçı, S. (2014). Sosyal Medya Gazeteleri Nasıl Etkiliyor? Haberlerin Twitter'da 
Yayılması Üzerine Bir Araştırma. The Turkish Online Journal of Design, Art and Communication - Tojdac, 4 (2), 40-52.

Taş, G. (2015). Sosyal Medya Tarihçesi. (Erişim: 01/01/2018), http://www.dijitalajanslar.com/sosyalmedya-tarihcesi/

Törenli, N. (2005). Yeni Medya, Yeni İletişim Ortamı. Ankara: Bilim ve Sanat Yayınları.

Uyanıkoğlu, C. (2017). En Çok Ziyaret Edilen Forum Siteleri (2017). (Erişim: 01/01/2018), http://www. kolaydata.com/en-cok-ziyaret-edilen-forum-siteleri2017-4130.html

Uzundağ, Ş. (2013). Türkiye'de Internet Bankacılı̆̆ının Gelişimi Ve İnternet Bankacılı̆̆ına İlişkin Tüketici Davranışları Analizi. Aydın İli Merkezinde Görev Yapan Öğretmenler Üzerine Bir Araştırma. Yüksek Lisans Tezi. Aydın: Adnan Menderes Üniversitesi.

Yıldırım, A. (2014). İnternetin Görünen Yüzü. KMÜ Sosyal ve Ekonomik Araştırmalar Dergisi, 16 (Özel Sayı I), 5159.

Yılmaz, P. (2016). Sosyal Medyanın İnsan Kaynakları Yönetiminde İşe Alım Süreci Üzerindeki Etkisi. ABMYO Dergisi, 41, 35-50. 